\title{
PERAN PEMBIAYAAN PRODUKTIF BMT MANDIRI MULIA TERHADAP PENINGKATAN KESEJAHTERAAN ANGGOTA PERSPEKTIF MAQASIH SYARIAH ${ }^{11}$
}

\author{
Muhammad Hidayatulloh \\ Mahasiswa Program Studi S1 Ekonomi Islam - Fakultas Ekonomi dan Bisnis \\ Universitas Airlangga \\ Email: hidayat.mh93.mh@gmail.com \\ Meri Indri Hapsari \\ Departemen Ekonomi Syariah - Fakultas Ekonomi dan Bisnis - Universitas Airlangga \\ Email:meri.indri@gmail.com
}

\begin{abstract}
:
The purpose of this study is to understand and analyze the role of BMT Mandiri Sejahtera Financing Productive for members welfare improvement. Method used in this study was descriptive qualitative approach with the case-study research. This research had analysis unit which were BMT Mandiri Sejahtera Financing Productive and welfare improvement of the members that received the financing activities.

The result of this study was that the BMT Mandiri Sejahtera Financing Productive took role in improving the walfare of the members. Welfare was measured by using the 5 indicators of basic needs maintanance, based on maqashid syariah, which are the religion maintanance, life maintenance, upkeep sense, descendants maintenance, and property maintenance. The improvement of welfare experienced by the members were different. Generally, the walfare improvement of the members who received BMT Mandiri Sejahtera only happened in several basic needs maintanance.
\end{abstract}

Keywords: Financing, Baitul Maal wat Tamwil, Welfare, Maqashid Syariah

\section{PENDAHULUAN}

Ekonomi Islam mengalami kemajuan yang sangat pesat, baik dari segi kajian akademis maupun dalam praktek operasional. Kemajuan ekonomi Islam dari segi kajian akademis dikembangkan melalui pengajaran pada universitasuniversitas di berbagai negara, dari segi praktek, tercermin dengan berdirinya lembaga-lembaga keuangan Islam baik perbankan maupun non-perbankan. Perkembangan industri keuangan Islam di Indonesia sendiri mulai mendapatkan momentum sejak didirikannya Bank Muamalat Indonesia pada tahun 1991 (Antonio, 2001:25). Sejak saat itu, terbit berbagai regulasi yang memberikan ruang bagi bank konvensional untuk dapat membuka sistem pelayanan syariah pada cabangnya (dual banking system).

Data statistik perbankan syariah Bank Indonesia pada tahun 2014 mencatat. Terdapat 12 Bank Umum Syariah yang telah memiliki 2.151 unit kantor cabang syariah, dan 22 bank umum konvensional yang memiliki Unit Usaha Syariah yang telah memiliki 320 kantor cabang. Meskipun perkembangan perbankan syariah sudah cukup pesat, namun hal tersebut belum merefleksikan keberhasilan perkembangan industri keuangan syariah secara utuh jika tidak diiringi oleh pertumbuhan lembaga keuangan syariah

1) Jurnal ini merupakan bagian dari skripsi dari Muhammad Hidayatulloh, NIM: 041114078 , yang diuji pada 26 Oktober 2015 
yang lain. Sistem keuangan yang adil dan efisien dapat terwujud jika setiap tipe dan lapisan masyarakat dapat terwadahi keinginannya dalam berinvestasi dan berusaha. (Sudarsono, 2012:7). Kenyataannya perbankan syariah belum mampu menjangkau masyarakat secara menyeluruh, khususnya masyarakat menengah kebawah, padahal disanalah sektor usaha mikro, kecil, dan menengah (UMKM) berada (Antonio dan Nugraha, 2013:125).

Sektor usaha mikro, kecil ,dan menegah (UMKM) merupakan tiang sekaligus urat nadi bagi perekonomian Indonesia karena sektor ini memiliki kontribusi yang begitu besar bagi perekonomian Indonesia,Hal tersebut dapat kita lihat dari tabel berikut:

Tabel 1.

Data Usaha Mikro, Kecil, Menengah (UMKM) Dan Usaha Besar (UB) Tahun 2012

\begin{tabular}{|c|c|c|c|c|}
\hline NO & INDIKATOR & SATUAN & JUMLAH & PANGSA \\
\hline \multirow[t]{3}{*}{1} & Unit Usaha & & & \\
\hline & $\begin{array}{l}\text { Usaha Mikro, } \\
\text { Kecil, dan } \\
\text { Menengah }\end{array}$ & Unit & 56.534 .592 & 99,99 \\
\hline & Usaha Besar & Unit & 4.968 & 0,01 \\
\hline \multirow[t]{3}{*}{2} & Tenaga Kerja & & & \\
\hline & $\begin{array}{l}\text { Usaha Mikro, } \\
\text { Kecil, dan } \\
\text { Menengah }\end{array}$ & Orang & 107.657 .509 & 97,16 \\
\hline & Usaha Besar & Orang & 3.150 .645 & 2,84 \\
\hline \multirow[t]{3}{*}{3} & $\begin{array}{l}\text { PDB Atas Dasar } \\
\text { Harga Berlaku }\end{array}$ & & & \\
\hline & $\begin{array}{l}\text { Usaha Mikro, } \\
\text { Kecil, dan } \\
\text { Menengah }\end{array}$ & Rp Milyar & $4.869 .568,1$ & 59,08 \\
\hline & Usaha Besar & Rp Milyar & $3.372 .296,1$ & 40,92 \\
\hline \multirow[t]{3}{*}{4} & $\begin{array}{l}\text { PDB Atas Dasar } \\
\text { Harga Konstan } \\
2000\end{array}$ & & & \\
\hline & $\begin{array}{l}\text { Usaha Mikro, } \\
\text { Kecil, dan } \\
\text { Menengah }\end{array}$ & Rp Milyar & $1.451 .460,2$ & 57,48 \\
\hline & Usaha Besar & Rp Milyar & $1.073 .660,1$ & 42,52 \\
\hline
\end{tabular}

Sumber: Kementerian koperasi dan UMKM
Tabel 1. menunjukkan bahwa sektor usaha mikro, kecil, dan menengah (UMKM) memiliki kontribusi yang begitu besar bagi perekonomian Indonesia. Sektor ini memiliki $99,99 \%$ unit usaha jika ditotal dari keseluruhan unit usaha secara nasional, lalu sektor ini juga mampu menyerap $97,16 \%$ tenaga kerja di Indonesia, selanjutnya sektor ini juga berkontribusi terhadap PDB sebesar 59,08\% atas dasar harga berlaku dan $57,48 \%$ atas dasar harga konstan. Perbankan dinilai belum mampu untuk menjangkau sektor UMKM secara menyeluruh dikarenakan sistem perbankan yang dinilai sulit diakses oleh sebagian UMKM, dalam hal persyaratan teknis, terutama soal agunan dan persyaratan administratif lainnya (Rivai, 2013:701).

Kehadiran lembaga keuangan mikro sangat diperlukan untuk membantu permodalan dalam rangka menguatkan sektor ini. Salah satu contoh adalah lembaga keuangan mikro Islam yaitu Baitul Maal Wat Tamwil (BMT). BMT dinilai mampu untuk membantu masyarakat menengah kebawah karena peran umum BMT adalah melakukan pembinaan dan pendanaan yang berdasarkan sistem syariah. Peran ini menegaskan arti penting prinsip-prinsip syariah dalam BMT dalam kehidupan masyarakat (Sudarsono, 2012:107). BMT bukan sekedar berperan membantu masyarakat dalam hal permodalan tapi juga membantu masyarakat agar terlepas dari sistem 
bunga (riba) yang dilarang dalam agama.

Pada pasal 3 Undang-Undang Nomor 25 tahun 1992 disebutkan bahwa fungsi koperasi adalah memajukan kesejahteraan anggota pada khususnya dan masyarakat pada umumnya, serta ikut membangun tatanan perekonomian nasional dalam rangka mewujudkan masyarakat adil dan makmur. Sesuai Undang-Undang tersebut, maka secara konseptual BMT yang merupakan lembaga keuangan berbadan hukum koperasi memiliki tanggung jawab untuk mensejahterahkan anggotanya. Harapannya, keberadaan BMT melalui pembiayaan yang disalurkannya mampu untuk membantu anggota dalam hal permodalan sehingga mampu untuk meningkatkan atau mengembangkan usaha anggota sekaligus pendapatan anggota yang ujungnya adalah meningkatkan kesejahteraan anggota dari anggota itu sendiri.

Objek dalam penelitian ini adalah BMT Mandiri Mulia. BMT Mandiri Mulia adalah salah satu BMT yang beroperasi di Gresik Jawa Timur. BMT ini memiliki perkembangan kinerja keuangan yang begitu baik sehingga peneliti tertarik untuk melakukan penelitian pada BMT ini. Berikut perkembangan kinerja keuangan dilihat dari segi aset dan pembiayaan BMT Mandiri Mulia selama lima tahun terahir:

Tabel 2.

Aset dan Pembiayaan BMT Mandiri Mulia Selama Lima Tahun Terakhir

\begin{tabular}{|l|l|l|l|l|}
\hline Tahun & \multicolumn{1}{|c|}{ Aset (Rp) } & $\begin{array}{c}\text { Kenaikan } \\
(\%)\end{array}$ & $\begin{array}{c}\text { Pembiayaan } \\
(\mathbf{R p})\end{array}$ & $\begin{array}{c}\text { Kenaikan } \\
(\%)\end{array}$ \\
\hline 2010 & 5.799 .291 .087 & 0 & 6.580 .325 .402 & 0 \\
\hline 2011 & 10.461 .134 .554 & 80.3 & 9.743 .671 .412 & 48.1 \\
\hline 2012 & 22.230 .236 .796 & 112.5 & 18.140 .601 .900 & 86.2 \\
\hline 2013 & 35.824 .159 .104 & 61.2 & 25.914 .976 .400 & 42.8 \\
\hline 2014 & & & & \\
\hline
\end{tabular}

Sumber: Laporan pertanggungjawaban pengurus dan pengelola BMT Mandiri Mulia Tahun 2014.

Tabel 2. menunjukkan bahwa aset dan pembiayaan BMT Mandiri Mulia mengalami peningkatan setiap tahunnya. Pada tahun 2011 aset meningkat sebesar $80,3 \%$ dan pembiayaan meningkat sebesar 48, 1\%; kemudian pada tahun 2012 aset meningkat sebesar $112,5 \%$ dan pembiayaan meningkat sebesar $86,2 \%$; lalu pada tahun 2013 aset meningkat sebesar $61,2 \%$ dan pembiayaan meningkat sebesar 42,8\%; selanjutnya pada tahun 2014 aset meningkat sebesar $44,9 \%$ dan pembiayaan meningkat sebesar 9,6\%. Hal ini yang mendasari penulis memilih BMT Mandiri Mulia sebagai objek penelitian dikarenakan BMT Mandiri Mulia memiliki jumlah pembiayaan yang begitu besar dan juga mengalami peningkatan yang cukup tinggi tiap tahunnya.

Berdasarkan uraian latar belakang di atas maka dapat dirumuskan pertanyaan yang dijadikan acuan dalam penelitian ini, yaitu bagaimana peran pembiayaan produktif BMT Mandiri Mulia bagi peningkatan kesejahteraan anggota dalam perspektif maqashid syariah?. 
Adapun tujuan dari penelitian ini adalah untuk mengetahui dan menganalisis peran pembiayaan produktif BMT Mandiri Mulia terhadap peningkatan kesejahteraan anggota.

\section{LANDASAN TEORI}

Kamus besar bahasa Indonesia mendefinisikan peran sebagai seperangkat tingkah yang diharapkan dimiliki oleh orang yang berkedudukan dimasyarakat. Suhardono (1994:3) lebih lanjut menyatakan bahwa makna peran dapat dijelaskan sebagai berikut:

A. Karakteristik yang disandang untuk dibawakan oleh seorang actor dalam pentas drama.

B. Fungsi yang dibawakan seseorang ketika menduduki suatu posisi dalam struktur sosial.

Undang-undang Nomor 10 Tahun 1998 tentang perbankan mendefinisikan pembiayaan berdasarkan prinsip syariah adalah penyediaan vang atau tagihan yang dapat dipersamakan dengan itu berdasarkan persetujuan atau kesepakatan antara bank dan pihak lain yang mewajibkan pihak yang dibiayai untuk mengembalikan uang atau tagihan tersebut setelah jangka waktu tertentu atau dengan imbalan atau bagi hasil. Berbeda dengan kredit, dimana pihak pihak peminjam diwajibkan melunasi utangnya setelah jangka waktu tertentu dengan pemberian bunga.

Muhammad (2002:17) menyatakan bahwa secara umum tujuan pembiayaan dibedakan menjadi dua, yaitu: tujuan pembiayaan untuk tingkat makro dan tujuan pembiayaan untuk tingkat mikro. Antonio (2001:160) me

Antonio (2001;160) menyatakan bahwa, pembiayaan merupakan salah satu tugas pokok bank Islam, yakni memberikan fasilitas penyediaan dana untuk memenuhi kebutuhan pihak-pihak yang merupakan defisit unit.

Pengertian lembaga keuangan mikro apabila dikaitkan dengan kata Islam, dapat dipahami bahwa lembaga kevangan mikro Islam adalah badan yang melalukan kegiatan-kegiatan dibidang keuangan dengan menarik vang dari masyarakat dan menyalurkan vang tersebut kembali ke masyarakat dengan menggunakan prinsip nilai-nilai ajaran Islam. Lembaga kevangan mikro Islam dapat berbentuk Baitul Mal Wattamwil (BMT), Koperasi Syariah dan Bank Perkreditan Rakyat Syari'ah (BPRS).

Baitul mal wat tamwil berasal dari dua istilah yakni baitul mal dan baitul tamwil. Baitul mal lebih mengarah ada usahausaha peghimpunan dan penyaluran dana yang non profit, seperti zakat, infaq, dan shodaqoh, sedangkan baitul tamwil mengarah pada usaha penghimpunan dan penyaluran dana komersial (Sudarsono, 2012:107). Baitul tamwil juga dapat berarti rumah penyimpanan harta milik pribadi yang dikelola oleh lembaga. Lembaga ini didirikan dengan maksud untuk memfasilitasi kalangan masyarakat menegah kebawah yang tidak tersentuh oleh layanan perbankan. 
BMT memiliki beberapa peranan diantaranya menurut Sudarsono (2012:108) adalah sebagai berikut:

A. Menjauhkan masyarakat dari praktek ekonomi yang bertentangan dengan syar'i BMT harus mampu berperan aktif dalam mengedukasi masyarakat mengenai ekonomi syariah.

B. Memberikan pendanaan dan pembinaan usaha kecil. BMT bukan hanya sekedar memberikan pinjaman modal melainkan juga harus melakukan pendampingan, pembinaan, penyuluhan dan pengawasan terhadap usaha yang dijalankan nasabah.

C. Melepaskan masyarakat dari ketergantungan terhadap rentenir. BMT harus mampu memberikan layanan yang lebih baik sehingga bisa mengalihkan masyarakat yang biasanya menggunakan jasa rentenir menjadi ke BMT.

D. Menjaga keadilan ekonomi masyarakat dengan distribusi yang merata. Dalam hal ini, BMT harus mampu melakukan pemetaan skala prioritas atas nasabah yang memerlukan perhatian lebih.

BMT merupakan lembaga keuangan non bank yang bersifat sosial dan bisnis dalam rangka memperbaiki perekonomian umat, oleh karena itu dana yang telah berhasil dikumpulkan dari anggota harus disalurkan kembali kepada anggota dalam bentuk pembiayaan.
Pembiayaan yang diberikan oleh BMT memiliki orientasi untuk mengembangkan dan meningkatkan pendapatan bagi anggota. Sasaran pembiayaan adalah semua sektor ekonomi, seperti pertanian, industri rumah tangga, pendagangan dan jasa. Ada berbagai jenis pembiayaan yang diberikan oleh BMT, yang mana semua itu mengacu pada dua jenis akad yaitu syirkah dan jual beli.

Muhammad

(2000:119-120) menyatakan bahwa kedua jenis akad diatas kemudian dikembangkan sesuai dengan kebutuhan yang dikehendaki oleh BMT dan anggotanya. Diantara pembiayaan yang sudah umum dijalankan oleh BMT, yaitu:
A. Pembiayaan bai' bi tsaman ajil.
B. Pembiayaan murabahah.
C. Pembiayaan mudharabah.
D. Pembiayaan musyarakah.
E. Pembiayaan qardh hasan.

BMT juga mengelola dana ibadah seperti zakat, infaq, dan shodaqoh (ZIS) yang dalam hal ini BMT dapat berfungsi sebagai amil (Muhammad, 2000:117).

Islam memaknai kesejahteraan dengan istilah falah. Falah berasal dari kata kerja dalam bahasa Arab aflahayuflihu yang berarti kesuksesan, kemuliaan dan kemenangan dalam hidup (P3El, 2008:2). Falah secara istilah berarti kesejahteraan holistik dan seimbang antara dimensi material-spiritual, individusosial dan kesejahteraan di kehidupan duniawi dan akhirat. Kesejahteraan (falah) dapat terwujud apabila terpenuhi 
kebutuhan-kebutuhan hidup manusia secara seimbang sehingga tercapai maslahah. Maslahah adalah segala bentuk keadaan baik material maupun nonmaterial yang mampu meningkatkan kedudukan manusia sebagai makhluk yang paling mulia (P3El, 2008:5). Islam mendefinisikan

kesejahteraan beradasarkan pandangan yang konfrehensif, P3EI (2008: 4-5) menjelaskan bahwa kesejahteraan menurut ajaran Islam mencakup dua pengertian, yaitu:

A. Kesejahteraan holistik dan seimbang Kecukupan materi yang didukung oleh terpenuhinya kebutuhan spiritual individu dan sosial. Manusia merupakan makhluk yang terdiri dari unsur fisik dan jiwa sehingga kebahagiaan haruslah menyeluruh antara kedua hal tersebut. Manusia adalah individu yang merupakan bagian dari lingkungan sosial sehingga manusia akan dapat bahagia jika dapat menjaga keseimbangan antara dirinya dengan lingkungan sosialnya.

B. Kesejahteraan dunia dan akhirat

Manusia tidak hanya hidup di alam dunia saja, tetapi juga hidup di alam setelah kematian (akhirat). Setiap manusia ingin mendapatkan kebahagiaan yang abadi atau sepanjang masa hidupnya, tidak hanya dalam kehidupan ini tapi juga kehidupan di akhirat kelak.

Kesejahteraan dalam pandangan Islam tidak hanya dinilai dengan ukuran material saja melainkan juga dinilai dengan ukuran non-material yang meliputi, terpenuhinya kebutuhan spiritual, terpeliharanya nilai-nilai moral, dan terwujudnya keharmonisan sosial. Hal ini berarti terdapat keseimbangan antara dunia dan akhirat. Allahberfirman:

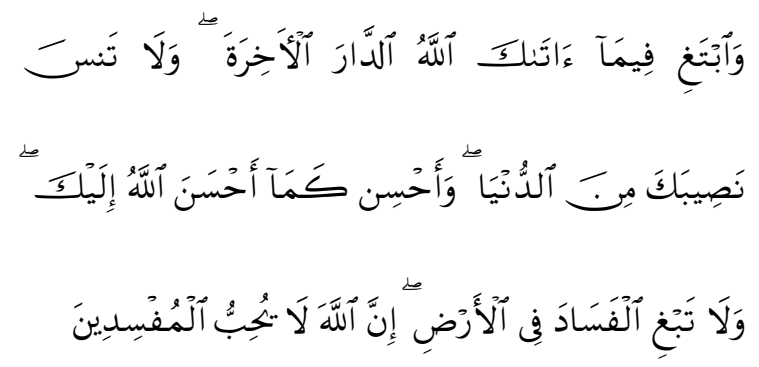

wabtaghi fiimaa aataaka allaahu alddaara al-aakhirata walaa tansa nashiibaka mina alddunyaa wa-ahsin kamaa ahsana allaahu ilayka walaa tabghi alfasaada fii al-ardhi inna allaaha laa yuhibbu almufsidiina "Dan carilah pada apa yang telah dianugerahkan Allah kepadamu (kebahagiaan) negeri akhirat, dan janganlah kamu melupakan bahagianmu dari (kenikmatan) duniawi dan berbuat baiklah (kepada orang lain) sebagaimana Allah telah berbuat baik kepadamu, dan janganlah kamu berbuat kerusakan di (muka) bumi. Sesungguhnya Allah tidak menyukai orang-orang yang berbuat kerusakan."(QS. Al-Qashash: 77)

As-Syatibi menjelaskan bahwa kesejahteraan adalah terpenuhinya maslahah dasar bagi kehidupan manusia terdiri dari pemeliharaan lima hal, yaitu: agama (dien), jiwa, (nafs), akal, ('aql), keluarga dan keturunan (nasl), dan harta (mal). Kelimanya merupakan kebutuhan mutlak yang harus dipenuhi agar manusia dapat hidup bahagia didunia dan akhirat. Jika salah satu dari kelima hal tersebut tidak dapat terpenuhi, maka 
kebahagiaan hidup juga tidak dapat tercapai dengan sempurna (P3El, 2008:5).

Al-Ghazali mengartikan kesejahteraan dalam sebuah kerangka hierarki utilitas individu dan sosial yang meliputi: kebutuhan dasar (dharuriyat), kesenangan atau kenyamanan (hajiyyat), dan kemewahan (tahsiniyyat) (Karim, 2007:62). Sumar'in (2013:96) menjelaskannya sebagai berikut:

A. Dharuriyat adalah sesuatu yang mesti ada untuk tercapainya kebahagiaan dunia dan akhirat. Tanpa pemenuhan kebutuhan ini kebahagiaan dunia dan akhirat akan terancam.

B. Hajiyat adalah sesuatu yang dibutuhkan untuk menghilangkan kesempitan yang dapat menyebabkan kesulitan dan kesukaran dalam melaksanakan suatu kewajiban, tetapi kesulitan itu tidak sampai pada tingkat dharuriyah.

C. Tahsiniyah adalah melaksanakan kebiasaan-kebiasaan yang baik dan menghindari sesuatu yang dianggap kotor dan tidak baik menurut akal yang sehat, yang kesemua itu tercakup dalam akhlakul karimah

Secara umum, seseorang dikatakan sejahtera apabila telah mampu memenuhi kebutuhan hidup dasar/pokok (dharuriyat. Penelitian ini menggunakan pemeliharaan kelima hal diatas sebagai indikator kesejahteraan, yaitu agama (dien), jiwa, (nafs), akal, ('aql), keluarga dan keturunan (nasl), dan harta (mal). Alasan pengunaan indikator tersebut dikarenakan dianggap lebih lengkap dibandingkan dengan pengukuran kesejahteraan dari berbagai referensi yang didapatkan.

Proposisi penelitian ini adalah penyaluran pembiayaan produktif Baitul Mal wat Tamwil dapat berperan dalam peningkatan kesejahteraan anggota.

\section{METODE PENELITIAN}

Metode penelitian yang digunakan dalam penelitian ini adalah pendekatan kualitatif deskriptif dengan jenis penelitian studi kasus (Yin, 2008:18). Unit analisis dalam penelitian ini adalah pembiayaan produktif BMT Mandiri Mulia dan peningkatan kesejahteraan anggota yang menerima pembiayaan. Teknik analisis yang digunakan dalam penelitian ini adalah reduksi data, penyajian data, serta kesimpulan dan verifikasi. Dari hasil penelitian akan di deskripsikan dalam bentuk uraian.

\section{HASIL dan PEMBAHASAN}

BMT Mandiri Mulia berdiri pada tahun 2004 dan mulai beroperasi pada tahun 2005. Pada saat itu berdiri dengan nama Koperasi BMT Kube Sejahtera unit 023. Cikal bakal berdirinya BMT Mandiri Mulia berawal dari utusan desa Karangcangkring untuk mengikuti pelatihan tentang pemberdayaan ekonomi masyarakat di Yogyakarta pada tahun 2004 yang kemudian membentuk koperasi dengan modal awal sebesar Rp 125.000.000 yang berasal dari dana hibah Departemen Sosial. Koperasi BMT Kube Sejahtera unit 023 merupakan program 
binaan Direktorat BSFM Dirjen Banjamsos Departemen Sosial RI yang bekerja sama dengan PINBUK. Kemudian pada tahun 2005 terdapat modal tambahan sebesar Rp 22.000.000 yang berasal dari 38 anggota saat itu. Pada 13 Juni 2006 BMT ini baru berbentuk badan hukum dengan Nomor 03.BH/403.62/IV/2006. Seiring berjalannya waktu akhirnya Koperasi BMT Kube Sejahtera unit 023 berganti nama menjadi KJKS BMT Mandiri Mulia Jawa Timur pada 20 Oktober 2011.

Identitas dan legalitas dari BMT Mandiri Mulia Jawa Timur yaitu:

Nama Koperasi : KOPERASI BMT MANDIRI MULIA JAWA TIMUR

Kelompok Koperasi : Simpan Pinjam

Tahun Berdiri : 2004

Badan Hukum : Nomor:

03/BH/403.62/VI/2006

$\begin{array}{ll}\text { Tanggal } & : 13 \text { Juni } 2006 \\ \text { No. NPWP } & : 02.529 .695 .5-612.000 \\ \text { No. SIUSP } & : \text { 206/403.56/SIUP.K/V/2007 } \\ \text { No. TDP } & : \text { 13.02.2.47.00242 } \\ \text { Alamat Lengkap } & : \text { Jl. Raya Pasar Kliwon } \\ & \text { RT } 01 \text { RW 01 } \\ \text { Desa } & \text { : Karangcangkring } \\ \text { Kecamatan } & \text { : Dukun } \\ \text { Kabupaten } & : \text { Gresik } \\ \text { Provinsi } & : \text { Jawa Timur }\end{array}$

No./Telp. $\quad: 081615327570$

E-mail : bmt_msjatim@yahoo.co.id

Visi BMT Mandiri Mulia adalah "Menjadi lembaga kevangan Mikro Syari'ah yang sehat, berkembang, dan terpercaya yang mampu melayani anggota masyarakat sekitar berkehidupan salam, penuh keselamatan, kedamaian dan kesejahteraan".

Misi BMT Mandiri Mulia adalah "Mengembangkan Koperasi BMT Mandiri Mulia Jawa Timur sebagai sarana gerakan pemberdayaan dan keadilan, sehingga terwujud kualitas masyarakat disekitar Koperasi BMT Mandiri Mulia Jawa Timur yang salam, penuh keselamatan, kedamaian dan kesejahteraan".

Struktur organisasi pada BMT Mandiri Mulia adalah sebagai berikut:

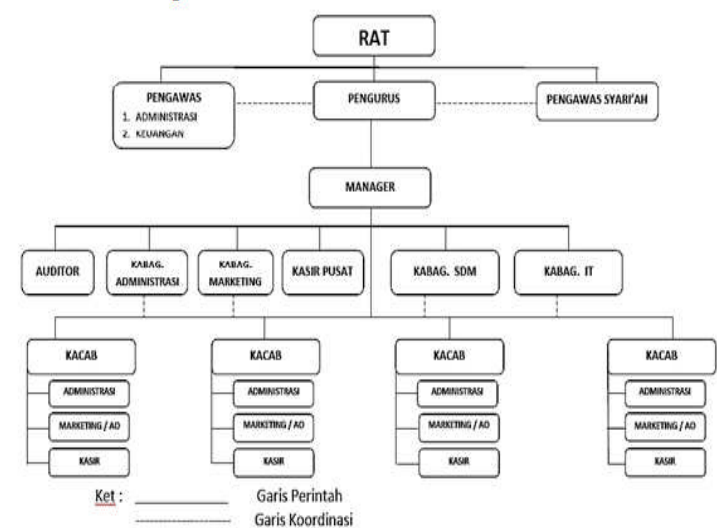

Sumber: BMT Mandiri Mulia

\section{Gambar 1.} Struktur Organisasi

Pada gambar 1. dapat dilihat bahwa terdapat dua pengawas, yaitu pengawas Syariah yang secara umum bertugas untuk memastikan operasional dan manajemen dari BMT ini sesuai aturan Syariah. Pengawas Syariah di BMT Mandiri Mulia Jawa Timur ini dipercayakan kepada bapak Ust. Ahmad Qusyaeri Burhanuddin, S. Ag. Sedangkan dari sisi pengawasan internal yang terdiri dari pengawas administrasi dan keuangan bertugas untuk memastikan segala kegiatan administrasi telah dilakukan dengan benar dan sesuai kaidah serta dari 
sisi keuangan, mengawasi transaksi sesuai dengan peruntukannya, dan memenuhi prinsip audit. Posisi ini dipercayakan kepada bapak H. Sudirman, SH., MH.

Secara umum, manajer memiliki tugas memimpin kegiatan operasional BMT sesuai dengan visi dan misi, serta target BMT. Tidak hanya itu, posisi manajer juga melakukan komunikasi terhadap pihak eksternal untuk menunjang kegiatan operasional BMT. Manajer secara langsung membawahi kepala cabang yang ditempatkan di setiap kantor dan posisi fungsionaris seperti kepala bagian (kabag) administrasi yang bertugas dalam pembukuan dan akuntabilitas BMT, kabag marketing yang bertugas untuk melakukan pemasaran dan mencari calon anggota dalam pendanaan maupun pembiayaan, kabag Sumber Daya Manusia (SDM) yang bertugas dalam melakukan perekrutan dan pengembangan SDM, Kabag Teknologi Informasi (IT) yang bertugas untuk membuat sistem informasi manajemen di BMT dalam rangka menunjang aktivitas operasional, Auditor untuk melaksanakan fungsi kontrol internal BMT, dan kasir pusat yang bertanggung jawab atas penerimaan dan pengeluaran vang. Posisi manajer sendiri di jabat oleh bapak H.M. Ayubi Chozin. Bapak Ayubi juga sebagai salah satu pendiri BMT Mandiri Mulia Jawa Timur. Setiap kepala cabang setidaknya membawahi administrasi, marketing, dan kasir.
Secara umum BMT Mandiri Mulia memiliki beberapa layanan jasa yang terdiri dari:

A. Produk Penghimpunan Dana

1) Simpanan Masyarakat Sejahtera (SIMASTER)

Simpanan dengan akad Wadiah Yadh Dhamanah, yaitu bentuk simpanan masyarakat yang dananya dapat ditarik sewaktuwaktu dengan pola titipan, dimana pihak penerima titipan dengan atau tanpa izin oleh pemilik barang untuk dapat mengelola dan memanfaatkan vang yang dititipkan (Muhammad, 2004: 6). Para anggota akan mendapatkan bonus secara sukarela dari BMT. Fasilitas yang diberikan paling lengkap, yaitu terima kiriman dan transfer dari atau ke bank lain. Produk SIMASTER memiliki beberapa kategori seperti SIMASTER Utama, SIMASTER Utama Khusus, dan SIMASTER Plus. Hal yang membedakan adalah terletak pada simpanan minimumnya dan bonus yang diberikan.

2) Simpanan Qurban

Simpanan dengan akad Wadiah Yadh Dhamanah yang tujuannya untuk membeli hewan qurban. Berbeda dengan SIMASTER, fasilitas yang diberikan tidak banyak, dan tabungan akan 
dicairkan ketika mendekati hari raya Idul Adha.

3) Simpanan Haji Mabrur Simpanan yang diperuntukkan untuk pendaftaran hingga pelunasan biaya ibadah haji.

4) Simpanan Lembaga

Simpanan yang khusus diperuntukkan bagi lembaga yang ingin menyimpan dananya di BMT, umumnya lembaga yang mengunakan produk ini adalah sekolah, masjid, pemerintah desa, dan sebagainya.

B. Produk Pembiayaan

1) Murabahah

Pembiayaan ini merupakan jual beli barang modal maupun barang konsumsi antara BMT selaku penjual dengan anggota selaku pembeli dengan nilai keuntungan dan jangka waktu pembayaran dimana harga perolehan diketahui oleh kedua pihak. Pembiayaan ini menempati posisi terbanyak di BMT Mandiri Mulia.

2) Mudharabah

Pembiayaan mudharabah adalah pembiayaan yang diberikan di mana BMT bertindak selaku shahibul maal dan anggota sebagai mudharib yang mengelola modal. Bagi hasil dihitung berdasarkan nisbah yang disepakati kedua pihak atas dasar pendapatan (revenue) atau pun keuntungan (profit) yang diperoleh. Risiko finansial yang terjadi akibat kerugian menjadi tanggungan BMT (shahibul maal) dan kerugian non-finansial menjadi tanggungan pengelola usah (mudharib). Alasan kurangnya minat masyarakat dalam menggunakan akad ini adalah sistemnya yang tidak se sederhana murabahah, salah satunya diwajibkan pelaporan di antara kedua pihak. Untuk itu, sangat sedikit para anggota menggunakan akad ini.

3) Rahn

Produk dengan akad ini termasuk fee based income, yaitu pendapatan BMT diperoleh dari upah yang sistematikanya yaitu anggota menitipkan barang gadai kepada BMT untuk menjaganya. BMT dapat meminta jasa/fee atas penjagaan, perawatan dan pemeliharaan. Akad ini di BMT Mandiri Mulia Jawa Timur digunakan pada produk talangan haji, dimana barang yang dititipkan merupakan dokumen-dokumen haji.

4) Qordh

pembiayaan ini merupakan pinjaman kebajikan dimana anggota hanya mengembalikan pokok pembiayaan saja dan anggota dapat memberikan 
infaq atau biaya administrasi. Pembiayaan ini ditujukan kepada para pedagang di sekitar BMT beroperasi yang dikenal baik dan memiliki karakter yang jujur dan baik, serta memiliki lapak di pasar sebagai persyaratan utama. Tujuan dari pembiayaan jenis ini adalah untuk menghilangkan rentenir yang ada di pasar.

C. Produk Jasa

Produk jasa yang ditawarkan meliputi:

1) Penukaran vang Ringgit dan valuta asing lainnya

2) Fasilitas kirim vang dari dalam atau luar negeri.

3) Pembayaran on-line payment berbagai produk seperti rekening listrik, air, pulsa, dan cicilan kendaraan bermotor dari berbagai perusahaan Leasing.

4) Fasilitas dana talangan haji.

D. Program Penyaluran Dana ZIS (Zakat, Infaq, Shadaqah)

BMT akan mengumpulkan zakat, infaq, shadaqah, hibah dan berbagai bentuk sumbangan lainnya, dari orang-orang yang peduli untuk disalurkan secara efektif dan efisien kepada kaum yang membutuhkan.

Peneliti dalam penelitian ini melakukan wawancara secara mendalam kepada seorang beberapa informan. Informan dalam penelitian ini berjumlah 10 orang yang merupakan anggota yang menerima pembiayaan dari BMT Mandiri
Mulia. Berdasarkan hasil penelitian dan analisis yang telah dilakukan, didapatkan bahwa informan yang mengalami peningkatan dalam pemeliharaan agama dapat dilihat pada gambar berikut:

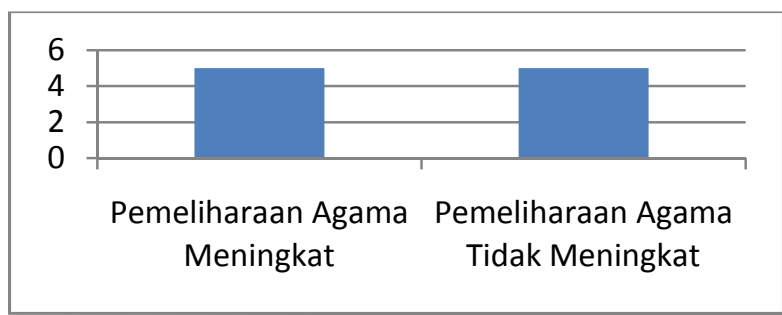

Gambar 2.

Persebaran Informan dalam Pemeliharaan Agama

Berdasarkan gambar 2. dapat dilihat bahwa lima informan mengalami peningkatan dalam pemeliharaan agama dan lima informan tidak mengalami peningkatan dalam pemeliharaan agama. Pemeliharaan agama dalam penelitian ini diukur dengan melihat dari pengeluaran untuk zakat, infaq, dan shodaqoh. Lima informan mengalami peningkatan dalam pemeliharaan harta karena usahanya yang semakin berkembang sehingga hasil usahnya juga terus meningkat sehingga kesadaran mengeluarkan zakat, infaq, dan shodaqoh juga meningkat. Kelima informan yang mengalami peningkatan dalam pemeliharaan agama adalah bapak Eko Iswandi, ibu Najiyah, bapak Wahyudin, bapak Edi Mulyono, dan bapak Suratno. Adapun lima informan lainnya yang tidak mengalami peningkatan dalam pemeliharaan agama dikarenakan hasil usahanya yang 
hanya cukup untuk memenuhi kebutuhan sehari-hari. Kelima informan tersebut adalah ibu Maslahatul Ummah, bapak Suyanto, bapak Sukadi, bapak Nariyaji, dan bapak Hasan.

Pada pemeliharaan jiwa, hasil yang didapat adalah:

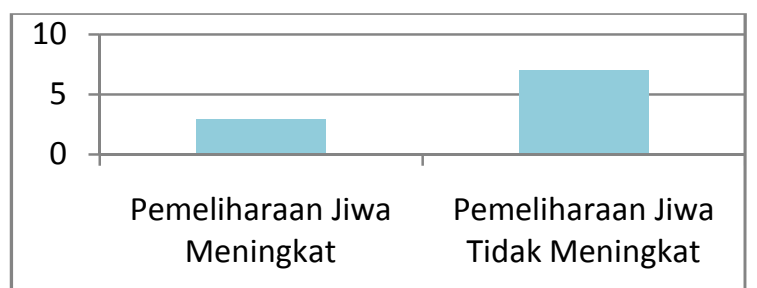

Gambar 3.

Persebaran Informan dalam Pemeliharaan Jiwa

Berdasarkan gambar 3. dapat dilihat bahwa tiga informan mengalami peningkatan dalam pemeliharaan jiwa dan tujuh informan tidak mengalami peningkatan dalam pemeliharaan jiwa. Pemeliharaan jiwa dilihat dari meningkatnya kemampuan informan dalam memenuhi kebutuhan pokok sehari-hari dan kemampuan dalam menjaga kesehatan. Ketiga informan yang mengalami peningkatan dalam pemeliharaan jiwa adalah bapak Eko Iswandi, bapak Wahyudin, dan bapak Suratno. Bahkan bapak Suratno sudah mulai mengikuti program BPJS kesehatan demi penjagaan jiwa dimasa depan. Adapun ketujuh informan yang tidak mengalami peningkatan dalam pemeliharaan jiwa dikarenakan hasil usaha yang memang hanya cukup untuk memenuhi kebutuhan secara sederhana dan bisa juga disebabkan oleh kebiasaan gaya hidup dari informan yang memang sederhana.

Pada pemeliharaan akal, hasil yang didapat adalah:

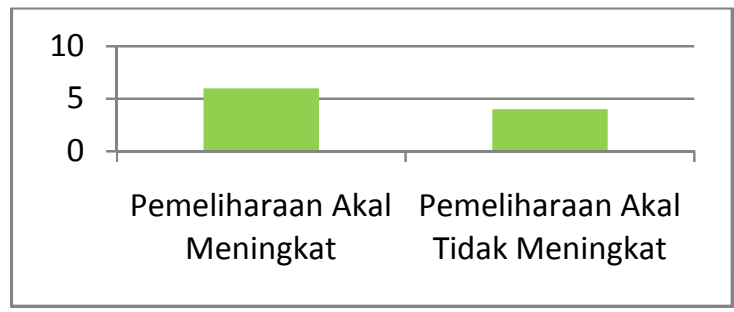

Gambar 4.

Persebaran Informan dalam Pemeliharaan

$$
\text { Akal }
$$

Berdasarkan gambar 4. dapat dilihat bahwa enam informan mengalami peningkatan dalam pemeliharaan akal dan empat informan tidak mengalami peningkatan dalam pemeliharaan akal. Peningkatan dalam pemeliharaan akal dalam penelitian ini diukur dengan melihat perkembangan kemampuan informan dalam mengembangkan usahanya. Adapun para informan yang mengalami peningkatan kesejahteraan dalam hal pemeliharaan akal adalahBapak Suyanto, Bapak Eko Iswandi, Ibu Najiyah, Bapak Wahyudin, Bapak Suratno, dan Bapak Hasan.

Pada pemeliharaan keturunan, hasil yang didapat dalah:

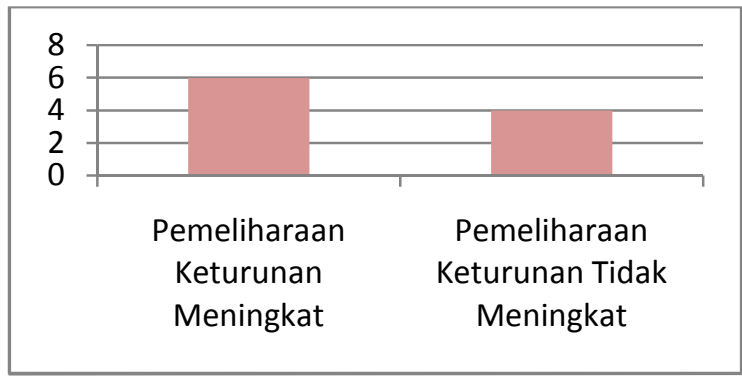

Gambar 5. 
Persebaran Informan dalam Pemeliharaan Keturunan

Berdasarkan gambar 5. dapat dilihat bahwa enam informan mengalami peningkatan dalam pemeliharaan keturunan sedangkan empat informan lainnya tidak mengalami peningkatan. Peningkatan pemeliharaan keturunan oleh informan setelah menerima pembiayaan dari BMT Mandiri Mulia tersebut bermacam-macam, ada yang mulai memasukkan anaknya kesekolah, ada yang sudah sekolah dan mengikutkan anak untuk kursus tambahan diluar sekolah, ada yang mulai memasukkan anaknya ke pondok pesantren, dan ada juga yang mempersiapkan masa depan anak dengan memberikan bekal usaha dagangan. Terjadinya peningkatan dalam pemeliharaan keturunan disebabkan adanya kesadaran oleh informan untuk mempersiapkan masa depan anak dengan baik. Informan yang mengalami peningkatan dalam pemeliharaan keturunan tersebut adalah ibu Maslahatul Ummah, bapak Eko Iswandi, ibu Najiyah, bapak Wahyudin, bapak Edi Mulyono, dan bapak Suratno.

Pada pemeliharaan harta, hasil yang didapat adalah:

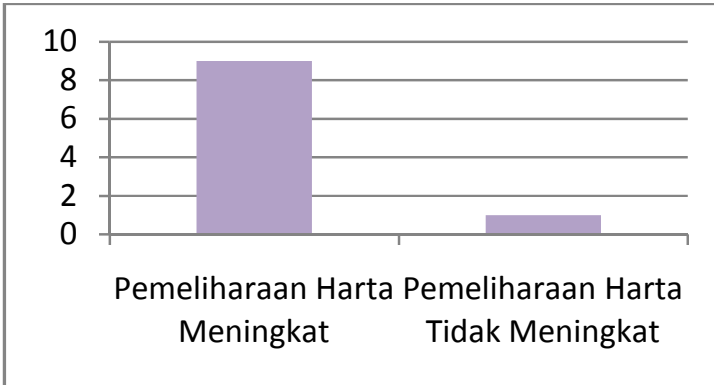

Gambar 6.

Persebaran Informan dalam Pemeliharaan Harta

Berdasarkan gambar 6. dapat dilihat bahwa sembilan informan mengalami peningkatan dalam pemeliharaan harta sedangkan seorang informan tidak mengalami peningkatan dalam pemeliharaan harta. Peningkatan pemeliharaan harta dalam penelitian ini erat kaitannya dengan jenis usaha yang dimiliki oleh informan dan dan alasan informan untuk mengajukan pembiayaan ke BMT Mandiri Mulia. Seorang informan yang tidak mengalami peningkatan harta merupakan seorang petani tambak. Berdasarkan keterangan yang didapatkan dari informan, hasil pertanian tidak mengalami peningkatan meskipun telah menerima pembiayaan dari BMT Mandiri Mulia. Hal itu dikarenakan jumlah atau area tambak yang digarap tidaklah bertambah sehingga otomatis hasil pertanian juga tidak ikut bertambah. Alasan informan tersebut mengajukan pembiayaan ke BMT Mandiri Mulia adalah digunakan sebagai tambahan modal karena biaya pengolahan tambak yang meningkat karena harga pupuk yang semakin meningkat disamping harga sewa tambak yang meningkat juga 
seperti yang dialami oleh bapak Nariyaji. Selain itu, tidak meningkatnya kesejahteraan informan dalam hal pemeliharaan harta adalah karena beliau mengaku satu-satunya sumber penghasilannya hanya berasal dari pertanian. Keterangan mengenai penghasilan seorang petani yang sulit untuk mengalami peningkatan juga dikuatkan oleh bapak Suyanto yang dulu pernah bertani dan bapak Suratno yang juga merupakan seorang petani tetapi memiliki penghasilan lain diluar pertanian. Sedangkan sembilan informan yang mengalami peningkatan kesejahteraan dalam pemeliharaan harta karena penghasilan mereka berasal dari usaha diluar pertanian meskipun ada yang penghasilannya berasal dari hasil pertanian akan tetapi ada penghasilan lain diluar itu. Dua informan yang mengalami peningkatan pemeliharaan harta juga memiliki pertanian akan tetapi pertanian bukan pengasilan utama bagi mereka, pertanian hanyalah sampingan. Kedua informan tersebut adalah bapak Suratno, dan bapak Hasan. Tujuh informan lainnya yang mengalami peningkatan pemeliharaan harta memiliki jenis usaha yang berbeda-beda mulai dari pedagang, jasa servis, hingga pengusaha, dimana usaha mereka semakin berkembang dari tahun ke tahun.

\section{Simpulan}

Pembiayaan produktif BMT Mandiri Mulia berperan dalam meningkatkan kesejahteraan anggota karena sebagian besar anggota mengalami peningkatan dalam pemeliharaan lima hal, yaitu agama, jiwa, akal, keturunan, dan harta. Meningkatnya kesejahteraan yang dirasakan oleh anggota dengan meningkatnya pemeliharaan lima kebutuhan sesuai maqashid syariah masing-masing adalah sebagai berikut:

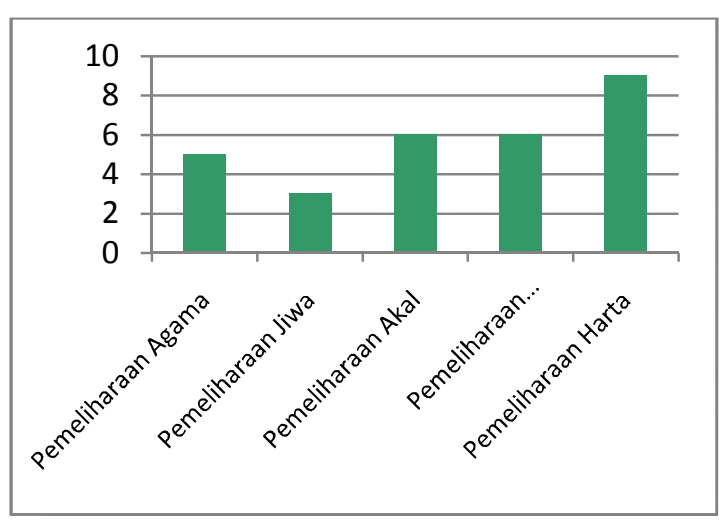

Gambar 7.

Peningkatan Masing-Masing Indikator Kesejahteraan Informan

Berdasarkan gambar 7. dapat dilihat bahwa dari 10 informan yang merupakan anggota yang menerima pembiayaan dari BMT mengalami peningkatan kesejahteraan yang berbeda-beda. Informan yang mengalami peningkatan dalam pemeliharaan agama sebanyak lima orang. Informan yang mengalami peningkatan dalam pemeliharaan jiwa sebanyak tiga orang. Informan yang mengalami peningkatan dalam pemeliharaan akal sebanyak enam orang. Informan yang mengalami peningkatan dalam pemeliharaan keturunan sebanyak enam orang. Terakhir, informan yang mengalami peningkatan dalam pemeliharaan harta sebanyak sembilan orang. 
Saran yang bisa diberikan dari penelitian ini adalah:

1. Bagi anggota penerima pembiayaan BMT yang berprofesi sebagi petani hendaknya meningkatkan kapasitas pertaniannya atau mencari penghasilan lain diluar pertanian sebagai sampingan agar kesejahteraannya mengalami peningkatan.

2. Bagi pihak BMT Mandiri Mulia untuk berkomunikasi lebih intensif dengan para anggotanya khususnya para anggota penerima pembiayaan dari BMT agar pihak BMT dapat mengetahui anggota pembiayaan mana saja yang tidak mengalami peningkatan kesejahteraan sehingga diharapkan mampu membantu meningkatkan kesejahteraan anggota secara maksimal.

\section{DAFTAR PUSTAKA}

Al-Qur'an Terjemahannya (Revisi terbaru)

Departemen Agama RI dengan translesterisasi Arab- Latin. 2001. Semarang. CV. Asy Syifa'

Antonio, Muhammad Syafi'i. 2001. Bank Syariah: Dari Teori ke Praktik. Jakarta: Gema Insani

Antonio, Muhammad Syafi'i dan Hilman F. Nugraha. 2013. Peran Intermediasi Sosial Perbankan Syariah bagi
Masyarakat Miskin. Jurnal Tsaqafah (Online). Vol. 9 No. 1, Tahun 2013

Muhammad. 2000. Lembaga-Lembaga Keuangan Umat Kontemporer Edisi satu Cetakan Pertama. Yogyakarta: UII Press Muhammad. 2002. Lembaga-Lembaga Kevangan Umat Kontemporer. Yogyakarta: UII Press

Pusat Pengkajian dan Pengembangan Ekonomi Islam (P3EI). 2008. Ekonomi Islam. Jakarta: PT Raja Grafindo Persada

Rivai, Veithzal,dkk. 2013. Financial Institution Management (Manajemen Kelembagaan Kevangan) Disajikan Secara Lengkap Dari Teori Hingga Aplikasi. Jakarta: PT RajaGrafindo Persada

Sudarsono, Heri. 2012. Bank dan Lembaga Keuangan Syariah Deskripsi dan Ilustrasi edisi ketiga. Yogyakarta: Ekonosia

Suhardono, Edy. 1994. Teori Peran: Konsep, Derivasi dan Implikasinya. Jakarta: Gramedia Pustaka Utama

Yin. 2002. Studi Kasus Desain \& Metode. Jakarta: PT Grafindo Persada 